\title{
Antioxidative and Neuroprotective Activities of Extracts from the Fruit Hull of Mangosteen (Garcinia mangostana Linn.)
}

\author{
Wanlop Weecharangsan ${ }^{a}$ Praneet Opanasopit ${ }^{a}$ Monrudee Sukma $^{a}$ \\ Tanasait Ngawhirunpat ${ }^{a}$ Uthai Sotanaphun ${ }^{a}$ Pongpan Siripong ${ }^{b}$ \\ ${ }^{a}$ Faculty of Pharmacy, Silpakorn University, Nakhonpathom, and b National Cancer Institute of Thailand, \\ Bangkok, Thailand
}

\section{Key Words}

Antioxidative activity · Neuroprotective activity •

Garcinia mangostana Linn.

\begin{abstract}
Objective: The aim of this study was to investigate the antioxidative and neuroprotective activities of various extracts from the fruit hull of mangosteen (Garcinia mangostana Linn., GM). Materials and Methods: Four extracts: water, $50 \%$ ethanol, $95 \%$ ethanol and ethyl acetate, were used. The antioxidative activity was evaluated using 2,2-diphenyl-1-picrylhydrazyl free-radical scavenging assay at extract concentrations of 1, 10,50 and $100 \mu \mathrm{g} / \mathrm{ml}$. Based on the free radical scavenging activity of the extracts, two (water and $50 \%$ ethanol) were selected for their protective activity in NG108-15 neuroblastoma cells against $\mathrm{H}_{2} \mathrm{O}_{2}$-induced oxidative stress and for cell viability using 3-(4,5-dimethylthiazol-2-yl)2,5-diphenyltetrazolium bromide assay. Results: All extracts exhibited antioxidative activity. The water and $50 \%$ ethanol extracts showed high free-radical scavenging activity with $\mathrm{IC}_{50}$ values of $34.98 \pm 2.24$ and $30.76 \pm$ $1.66 \mu \mathrm{g} / \mathrm{ml}$, respectively. Both water and $50 \%$ ethanol extracts exhibited neuroprotective activity on NG108-15 cells. The highest activity was observed at the concen-
\end{abstract}

tration of $50 \mu \mathrm{g} / \mathrm{ml}$ for both the water and $50 \%$ ethanol extracts. For cytotoxicity test, none of the extracts was toxic to the cells except at the high concentration of $100 \mu \mathrm{g} / \mathrm{ml}$. Conclusions: These results suggest that the water and $50 \%$ ethanol extracts from the fruit hull of GM may be potent neuroprotectants.

Copyright $(2006$ S. Karger AG, Basel

\section{Introduction}

Free radicals have been found to be crucial because they can cause several severe diseases such as cancer, cardiovascular and cell degeneration [1-3]. This damage results from the imbalance between antioxidants and free radicals in the body [4]. Thus efforts are being expended in the search for substances that can prevent and inhibit the activity of free radicals. An important source of antioxidants is daily vegetables and fruits $[1,5,6]$.

Oxidative stress-induced cell damage has been shown to be involved in neurodegenerative diseases such as Alzheimer's disease, Parkinson's disease, and stroke [7, 8]. The damage is mediated by reactive oxygen species (ROS), mainly superoxide anion $\left(\mathrm{O}_{2}^{\overline{1}}\right)$ and hydrogen peroxide $\left(\mathrm{H}_{2} \mathrm{O}_{2}\right)$. Accumulation of ROS in neuronal cells results in lipid peroxidation, protein and DNA damage,

\section{KARGER}

Fax +4161306 1234 E-Mail karger@karger.ch www.karger.com
(C) 2006 S. Karger AG, Basel

$1011-7571 / 06 / 0154-0281 \$ 23.50 / 0$

Accessible online at:

www.karger.com/mpp
Praneet Opanasopit

Department of Pharmaceutical Technology

Faculty of Pharmacy, Silpakorn University

Nakhonpathom 73000 (Thailand)

Tel. +66 34255 800, Fax +66 34255 801, E-Mail Praneet@email.pharm.su.ac.th 
and finally cell death [9]. Several studies revealed that ROS can be inhibited by antioxidants $[10,11]$.

The neuroprotective activity of various natural extracts has been reported in the literature [12-19]. The water extract of Curcuma longa reduces rat pheochromocytoma PC12 cell death induced by pyrogallol and $\mathrm{H}_{2} \mathrm{O}_{2}$ [12]. The water-soluble extracts of the seed of Celastrus paniculatus have neuroprotective effects against glutamate-induced toxicity in embryonic rat forebrain neuronal cells [13]. The ethanol extract of the seed of Vitis vinifera has neuroprotective effects on Mongolian gerbil forebrain [14].

Mangosteen is a tropical fruit available in south-east Asia. It has been used as traditional medicine to treat skin infections, wounds, and diarrhea. Several studies have revealed that xanthones from the fruit hull exhibit antimicrobial [15] and anti-inflammatory effects [16]. The ethanol extract of Garcinia mangostana Linn. (GM) inhibits histamine release, prostaglandin $\mathrm{E}_{2}$ synthesis [17], and HIV-1 protease [18]. The methanol extract of GM exhibits antiproliferative, apoptotic and antioxidative activities on SKBR3 human breast cancer cell line [19]. However, limited information is available on the neuroprotective activity of GM extracts. Previous reports revealed neuroprotective activities of antioxidative substances in various cell types. Curcumin exhibited dual action on $\mathrm{H}_{2} \mathrm{O}_{2}$-induced cell damage in NG108-15 cells [20]. The antioxidative activity of tert-butylhydroquinone showed protective activity against cell death in neuroblastoma SH-SY5Y cells [21]. Recently, Choto-san was shown to act as an antioxidant and neuroprotective agent against oxidative damage in NG108-15 cells [22]. In this study, we investigated the antioxidative and neuroprotective activity of the fruit hull extracts of $\mathrm{GM}$ against $\mathrm{H}_{2} \mathrm{O}_{2}-$ induced oxidative damage in neuroblastoma NG108-15 cells and the toxicity of the extracts on these cells.

\section{Materials and Methods}

\section{Materials}

Mangosteens (Garcinia mangostana Linn.) were obtained in Prajeenburi Province, Thailand. NG108-15 cell line was kindly provided by Prof. Haruhiro Higashida, Department of Biophysical Genetics, Molecular Medicine and Biotransformatics, Kanazawa University Graduate School of Medicine, Japan. 2,2-Diphenyl-1picrylhydrazyl (DPPH) and 3-(4,5-dimethylthiazol-2-yl)-2,5-diphenyl tetrazolium bromide (MTT) were purchased from Sigma Chemical Co., USA. Dulbecco's modified Eagle's medium and fetal bovine serum (FBS) were from GIBCO-Invitrogen, USA. Dimethyl sulfoxide (DMSO) was from BDH Laboratories, UK. All other chemicals were of analytical grade.

\section{Extraction}

The fruit bodies of mangosteen were cleaned to remove any residual compost. The hulls were separated and then dried. All dried hulls were ground and placed in $70^{\circ} \mathrm{C}$ distilled water at the ratio of hull powder:water of 1:4. The mixtures were boiled 4 times until no content of tannin was found by testing with $2 \%$ gelatin solution. The macerate filtrate was dried at $40-45^{\circ} \mathrm{C}$ in the hot air oven. The dry powder was macerated at room temperature for 7 days with distilled water, $50 \%$ ethanol, $95 \%$ ethanol or ethyl acetate. The extracts were filtered and evaporated to obtain the dry crude extracts. The obtained extracts were stored in a desiccator containing dry silica gel prior to use in each experiment.

Antioxidant Activity: DPPH Free Radical Scavenging Activity

The scavenging of DPPH free radicals was used for measuring the antioxidant activity of the extracts according to the method of Blois [23]. Briefly, stock solutions of the extracts were prepared by dissolving $0.1 \mathrm{~g}$ of dry extract in $50 \mathrm{ml} 50 \%$ methanolic solution. The stock solution was diluted with $50 \%$ methanolic solution to obtain sample solutions at the concentrations of $1,10,50$, and $100 \mu \mathrm{g} / \mathrm{ml}$. The sample solutions were thoroughly mixed with freshly prepared $0.01 \%$ DPPH methanolic solutions at the ratio of $1: 1$, and kept for $30 \mathrm{~min}$ in the dark at room temperature. The amount of the reaction mixture was determined by UV-VIS spectrophotometer (U-2000, Hitachi, Japan) at $517 \mathrm{~nm}$. The percentage of free radical scavenging activity was calculated as in the equation below:

$$
\begin{aligned}
& \text { DPPH inhibition }(\%)= \\
& 1-\frac{\text { Absorbance in the presence of extract }}{\text { Absorbance in the absence of extract }} \times 100
\end{aligned}
$$

The antioxidant activity of the extracts was expressed as $\mathrm{IC}_{50}$, defined as the concentration of the extract required to inhibit DPPH radicals by 50\%, using the exponential curve. Ascorbic acid was used as a standard antioxidant.

\section{Neuroprotective Activity}

Neuroprotectivity was evaluated in two separate protocols: neuropreventive and free radical scavenging activities using NG108-15 cells [24].

\section{Cell Culture}

NG108-15 cells were cultured in Dulbecco's modified Eagle's medium supplemented with 10\% FBS, hypoxanthine thymidine, aminopterin and minocycline solutions as a complete medium. The cells were cultured in $25-\mathrm{cm}^{2}$ flasks with $5 \mathrm{ml}$ complete medium and incubated at $37^{\circ} \mathrm{C}$ with $5 \% \mathrm{CO}_{2}$. The cells were subcultured every 3-4 days. Cells from passages $4-5$ were used for the experiments.

\section{MTT Assay for Cell Viability and Cytotoxicity}

The MTT assay was used to assess cell damage by the oxidants and cell viability protection by the extracts. A sample of $100 \mu \mathrm{l}$ MTT solution ( $1 \mathrm{mg} / \mathrm{ml}$ in medium without FBS) was added to each well of the 96 -well plates and then incubated for $3 \mathrm{~h}$ at $37^{\circ} \mathrm{C}$. The medium was removed and $100 \mu \mathrm{L}$ DSO was then added to each well and vigorously mixed to dissolve the formazan crystals. The eluted samples were measured directly in a microplate reader at 
$550 \mathrm{~nm}$ (Microplate Manager, Bio-Rad Laboratories, Hercules, Calif., USA). The percentage cell viability was calculated according to the equation below:

$$
\% \text { of cell viability }=\frac{\text { Absorbance of treated cells }}{\text { Absorbance of control cells }} \times 100
$$

\section{Experimental Design}

NG108-15 cells were plated at a density of $2 \times 10^{3}$ cells/well in 96-well plates and incubated at $37^{\circ} \mathrm{C}$ with $5 \% \mathrm{CO}_{2}$ for $48 \mathrm{~h}$. After 48-hour incubation, the cells were treated for the test experiments. To investigate the free radical scavenging or preventive activities of the extracts $[25,26]$, two different protocols were used.

Simultaneous Treatment. To assess the scavenging activities of the extracts, cells were simultaneously treated with the extracts and $\mathrm{H}_{2} \mathrm{O}_{2}$. The controls were optimal and normal cell cultures without addition of any extracts or oxidant agents, cells being exposed to oxidative damage without the presence of extracts. Cells were incubated at $37^{\circ} \mathrm{C}$ with $5 \% \mathrm{CO}_{2}$ for $2 \mathrm{~h}$, washed twice with PBS, and fresh media were added to the wells. Cell viability was determined by MTT assay.

Preincubation Treatment. For the preventive effect of the extracts on cells, the NG108-15 cells were preincubated with various concentrations of the extracts and incubated at $37^{\circ} \mathrm{C}$ with $5 \% \mathrm{CO}_{2}$ for $2 \mathrm{~h}$. After the removal of the media from the plates, cells were exposed to $200 \mu M \mathrm{H}_{2} \mathrm{O}_{2}$. Cells were incubated at $37^{\circ} \mathrm{C}$ with $5 \%$ $\mathrm{CO}_{2}$ for $2 \mathrm{~h}$, washed twice with PBS, and fresh media were added to the wells. Cell viability was determined by MTT assay.

Cytotoxicity Assay. The cells were incubated with various concentrations of the extracts at $37^{\circ} \mathrm{C}$ with $5 \% \mathrm{CO}_{2}$ for $20 \mathrm{~h}$. After 20-hour incubation, cell viability was determined using the MTT assay.

\section{Statistical Analysis}

Each experiment was performed at least 3 times. Sets of 7 or 8 wells for the MTT assay were used for each concentration of extracts. Results were expressed as means \pm SE. Data were analyzed by one-way analysis of variance (ANOVA) followed by LSD post hoc test. A p value $<0.05$ was considered statistically significant.

\section{Results}

\section{Extraction Yield and Antioxidative Activity of the GM Extracts}

The yield of the water, $50 \%$ ethanol, $95 \%$ ethanol and ethyl acetate extracts was 22.28, 2.01, 6.11 and $6.20 \%$, respectively. The water, $50 \%$ ethanol, $95 \%$ ethanol, ethyl acetate extracts and ascorbic acid solution showed scavenging activity with $\mathrm{IC}_{50}$ values of $34.98 \pm 2.24,30.76 \pm$ $1.66,58.46 \pm 0.98,77.84 \pm 0.57$ and $7.12 \pm 0.36 \mu \mathrm{g} / \mathrm{ml}$, respectively (table 1). Thus the water and $50 \%$ ethanol extracts had more effective scavenging activity than the extracts of $95 \%$ ethanol and ethyl acetate, but less than that of ascorbic acid solution, a standard antioxidant.
Table 1. Scavenging activity of DPPH radical of the water, $50 \%$ ethanol, $95 \%$ ethanol and ethyl acetate extracts

\begin{tabular}{lr}
\hline Extracts & $\mathrm{IC}_{50}, \mu \mathrm{g} / \mathrm{ml}$ \\
\hline Water extract & $34.98 \pm 2.24$ \\
$50 \%$ ethanol extract & $30.76 \pm 1.66$ \\
$95 \%$ ethanol extract & $58.46 \pm 0.98$ \\
Ethyl acetate extract & $77.84 \pm 0.57$ \\
Ascorbic acid solution & $7.12 \pm 0.36$
\end{tabular}

$\mathrm{IC}_{50}$ values are the concentrations scavenging 50\% DPPH radicals. Each value represents the mean \pm SE of three different measurements.

\section{Neuropreventive Activity}

As determined by MTT assay, oxidative stress by $\mathrm{H}_{2} \mathrm{O}_{2}$ resulted in a decrease in cell viability by $62.44 \pm$ $4.86 \%$ as compared with the control group (fig. 1). The water and $50 \%$ ethanol extracts showed the ability to inhibit cell death induced by $\mathrm{H}_{2} \mathrm{O}_{2}$. The activity of both extracts was found to be concentration-dependent at 1 and $50 \mu \mathrm{g} / \mathrm{ml}$ (fig. 1), however, a significant difference in neuroprotective activity was found only at the concentrations of 50 and $100 \mu \mathrm{g} / \mathrm{ml}$. The $50 \%$ ethanol extract exhibited higher activity than the water extract with 98.27 $\pm 5.79 \%$ and $74.89 \pm 7.56 \%$ cell viability, respectively. The neuroprotective activity of both extracts decreased at the concentration of $100 \mu \mathrm{g} / \mathrm{ml}$.

\section{Free Radical Scavenging Activity}

Similar results were obtained in the neuroprotective activity test. A decrease in cell viability $(52.34 \pm 2.3 \%)$ compared with the control group was also observed after $\mathrm{H}_{2} \mathrm{O}_{2}$-induced cell death. GM extracts exhibited free radical scavenging activity. Dose-dependent free radical scavenging activity was observed at concentrations of 1$50 \mu \mathrm{g} / \mathrm{ml}$ for both extracts (fig. 2). However, significant differences in free radical scavenging activity were found at high concentrations of 50 and $100 \mu \mathrm{g} / \mathrm{ml}$. The free radical scavenging activity of both extracts decreased at the concentration of $100 \mu \mathrm{g} / \mathrm{ml}$.

\section{Toxicity of GM Extracts on NG108-15 Cells}

The GM extracts in the concentration range of 1$50 \mu \mathrm{g} / \mathrm{ml}$ had no cytotoxicity (fig. 3). However, in the presence of $100 \mu \mathrm{g} / \mathrm{ml}$ of $50 \%$ ethanol extract, the viabil- 
Fig. 1. Neuropreventive activity of the water $(\square)$ and $50 \%$ ethanol ( $\square$ ) extracts in NG108-15 cells pretreated with GM extracts at various concentrations $(1,10,50$ and $100 \mu \mathrm{g} / \mathrm{ml}$ ) for $2 \mathrm{~h}$ and exposed to $\mathrm{H}_{2} \mathrm{O}_{2}$-induced oxidative stress. Two hours later, cell viability was determined by MTT assay. Each value represents the mean $\pm \mathrm{SE}$ of 3 wells. ${ }^{*} \mathrm{p}<0.05$; NS $=$ not significant.

Fig. 2. Free radical scavenging activity of the water $(\square)$ and $50 \%$ ethanol ( $\square$ ) extracts. NG108-15 cells were simultaneously treated with various concentrations of the GM extracts $(1,10,50$ and $100 \mu \mathrm{g} / \mathrm{ml})$ and $\mathrm{H}_{2} \mathrm{O}_{2}$. Two hours later, cell viability was determined by MTT assay. Each value represents the mean \pm SE of 3 wells. $* \mathrm{p}<0.05$; $\mathrm{NS}=$ not significant.

Fig. 3. Effect of the water ( $\square$ ) and $50 \%$ ethanol ( $\square$ ) extracts on the viability of NG10815 cells. Cells were incubated at $37^{\circ} \mathrm{C}$ with increasing concentrations of the GM extracts $(1,10,50$ and $100 \mathrm{~g} / \mathrm{ml})$ for $20 \mathrm{~h}$. The toxicity of the GM extracts was determined by MTT assay. Each value represents the mean \pm SE of 3 wells. $* \mathrm{p}<0.05 ; \mathrm{NS}=$ not significant.

ity of NG108-15 cells decreased to $39.45 \pm 6.93 \%$ compared to water extract, indicating toxicity to the cells, whereas the water extract led to a slight decrease in cell viability.

\section{Discussion}

NG108-15 cells are a neuroblastoma-glioma hybrid cell line possessing both neuronal and glial properties; they have been widely used as a neuron model in electrophysiology and pharmacology research [27, 28]. Hydrogen peroxide was chosen to induce oxidative cell damage in the cultures because oxidative stress is believed to be an important mediator of neuronal cell death, and has been postulated to contribute to the pathogenesis of various neurodegenerative diseases [29]. Equally important, $\mathrm{H}_{2} \mathrm{O}_{2}$ is a precursor of highly oxidizing, tissue-damaging radicals such as hydroxyl radicals and is known to be toxic to many systems [30]. Among a great variety of reactive oxygen species, $\mathrm{H}_{2} \mathrm{O}_{2}$ plays a pivotal role because it is generated from nearly all sources of oxidative stress. Exogenous $\mathrm{H}_{2} \mathrm{O}_{2}$ can enter the cells and induce cytotoxicity due to its high membrane permeability $[20,26]$.

A variety of biological activities such as antimicrobial, anti-inflammatory, antioxidative and antiproliferative activities have been revealed in the extracts of GM [16, $17,20]$. In this study, we determined the antioxidative activity of GM extracts by DPPH assay, which has been commonly used to evaluate the antioxidant activity of specific compounds or extracts $[31,32]$. The assay provides information on the reactivity of test compounds with a stable free radical. The bleaching of DPPH absorption is representative of the capacity of test compounds to scavenge free radicals independently of any enzymatic activity. The antioxidative activities of the extracts of water and $50 \%$ ethanol were higher than those of $95 \%$ ethanol and ethyl acetate extracts; however, they were lower than that of ascorbic acid solution as a standard antioxidant (table 1). Different solvents could extract a different amount of active compound due to distinct affinity of the compounds and the solvents. The results implied that the most active compounds responsible for antioxidant activity are in the 50\% ethanol extract. Our results clearly demonstrated that GM extracts were effective in scavenging DPPH radicals.

The ideal neuroprotective compound should not only exhibit free radical-scavenging activity but also modulate endogenous antioxidant defense systems. Activation of the function of endogenous antioxidant systems in tissue is the characteristic of antioxidant compounds. Many plant extracts or antioxidants have been reported to exert an indirect scavenging effect on free radical-induced tissue injury by activating the function of endogenous antioxidant systems. Previous reports $[25,26]$ have revealed that Chito-san and Ginkgo biloba extracts showed neuroprotective activity by using preincubation and simultaneous treatment. On the other hand, pretreatment with curcumin was unable to protect the cells from $\mathrm{H}_{2} \mathrm{O}_{2}$-induced oxidative damage, and instead caused a significant decrease in cell viability after $\mathrm{H}_{2} \mathrm{O}_{2}$ exposure [26]. Therefore, it is important to search for neuroprotective activity of GM extracts using two separate protocols: preventive and free radical scavenging activities. When the cells were treated with $200 \mu M$ of $\mathrm{H}_{2} \mathrm{O}_{2}$, the results showed that $\mathrm{H}_{2} \mathrm{O}_{2}$ reduced the viability to $50-60 \%$ of control. $\mathrm{H}_{2} \mathrm{O}_{2}$ formed by two-electron reduction of $\mathrm{O}_{2}$ is not a free radical but an oxidizing agent. In the presence of $\mathrm{O}_{2}$ and transition metal ions, $\mathrm{H}_{2} \mathrm{O}_{2}$ can generate $\mathrm{OH} \cdot$ via Fenton reaction. In addition, $\mathrm{H}_{2} \mathrm{O}_{2}$ can easily cross the cell membrane and exerts injurious effects on tissues through a number of different mechanisms, such as perturbing intracellular calcium homeostasis [33], decreasing intracellular ATP [34], inducing DNA damage [35], and inducing apoptosis [36]. Several previous studies have reported the neuroprotective effect of antioxidant and/or free radical-scavenging compounds against $\mathrm{H}_{2} \mathrm{O}_{2}$-induced cell damage in various assay systems. Thus the antioxidants appear to be closely related to the neuroprotective effect.

When added simultaneously with $\mathrm{H}_{2} \mathrm{O}_{2}$, GM extracts significantly protected $\mathrm{NG108-15}$ cells against $\mathrm{H}_{2} \mathrm{O}_{2}$-induced cell damage in a concentration-dependent manner at $1-50 \mu \mathrm{g} / \mathrm{ml}$, but not for $100 \mu \mathrm{g} / \mathrm{ml}$, compared to treatment with $\mathrm{H}_{2} \mathrm{O}_{2}$ alone (fig. 1). It is possible that the neuroprotective effect of $\mathrm{GM}$ extracts against the $\mathrm{H}_{2} \mathrm{O}_{2}$-induced decrease in cell viability may at least partly result from its antioxidant and free radical scavenging properties. Pretreatment with GM extracts was also able to protect NG108-15 cells from $\mathrm{H}_{2} \mathrm{O}_{2}$-induced oxidative damage, and instead caused a significant increase in cell viability after $\mathrm{H}_{2} \mathrm{O}_{2}$ exposure in a concentration-dependent manner at $1-50 \mu \mathrm{g} / \mathrm{ml}$, but not at $100 \mu \mathrm{g} / \mathrm{ml}$, compared to treatment with $\mathrm{H}_{2} \mathrm{O}_{2}$ alone (fig. 2). These results suggest that pretreatment of the cells with GM extracts could prevent cell damage by $\mathrm{H}_{2} \mathrm{O}_{2}$. Exposure to $\mathrm{GM}$ extract alone at the highest concentration $(100 \mu \mathrm{g} / \mathrm{ml})$ did alter cell viability over the incubation period in comparison with non- $\mathrm{H}_{2} \mathrm{O}_{2}$-treated control cells (fig. 3). This high concentration of extracts may cause significant toxicity in 
cells under normal conditions resulting in a slight decrease in free radical scavenging activity and neuropreventive activity (fig. 1, 2). 50\% ethanol extract showed more neuroprotective activity than the water extracts at all concentrations tested. This result was in accordance with the DPPH radical scavenging activity.

Summarizing our results, GM extracts have a potential to be neuroprotectant against oxidative stress-induced cell damage in neurodegenerative diseases such as Alzheimer's disease, Parkinson's disease and stroke. Although correlations between in vitro and in vivo results of GM extract have not yet been investigated, a good correlation has been reported in Alzheimer's disease [37], headache [38] and dementia [39] for some plants such as Choto-san, which has shown in vitro neuropreventive and free radical scavenging activity in NG108-15 cells.

\section{Conclusions}

This study demonstrates that the water and 50\% ethanol extracts exhibited antioxidative and neuroprotective activities in neuropreventive and free radical activities in an in vitro model. The extracts demonstrated no cytotoxicity except at the highest concentration of the extracts $(100 \mu \mathrm{g} / \mathrm{ml})$. This implies that GM extracts have a potential for neuroprotection in oxidative stress-induced cell damage in neurodegenerative diseases such as Alzheimer's disease, Parkinson's disease and stroke. However, in vivo studies for clinical data should be carried out.

\section{Acknowledgments}

The authors acknowledge the National Research Council of Thailand for supporting the research grant and the National Cancer Institute of Thailand for providing cell culture facilities.

\section{References}

1 Matés JM, Sánchez-Jiménez FM: Role of reactive oxygen species in apoptosis: implications for cancer therapy. Int $\mathrm{J}$ Biochem Cell Biol 2000;32:157-170

-2 Zimmerman MC, Davisson RL: Redox signaling in central neural regulation of cardiovascular function. Prog Biophys Mol Biol 2004;84: 125-149.

-3 Götz ME, Künig G, Riederer P, Youdim MBH: Oxidative stress: free radical production in neural degeneration. Pharmacol Ther 1994; 63:37-122.

4 Matés JM, Pérez-Gómez C, Núñez de Castro I: Antioxidant enzymes and human diseases. Clin Biochem 1999;32:595-603.

5 Weisburger JH: Mechanisms of action of antioxidants as exemplified in vegetables, tomatoes, and tea. Food Chem Toxicol 1999;37: 943-948.

6 Parejo I, Viladomat F, Bastida J, Rosas-Romero A, Saavedra G, Murcia MA, Jiménez AM, Codina C Jiménez AM, Codina C: Investigation of Bolivian plant extracts for their radical scavenging activity and antioxidant activity. Life Sci 2003;73:1667-1681.

7 Olanow CW:Aradical hypothesis forneurodegeneration. Trends Neurosci 1993;16:439-444

$>8$ Behl C: Alzheimer's disease and oxidative stress: implications for novel therapeutic approaches. Prog Neurobiol 1999;57:301-323.

$>9$ Coyle JT, Puttfarcken P: Oxidative stress. Science 1993;262:689-695.

10 Behl C: Vitamin E protects neurons against oxidative cell death in vitro more effectively than 17-beta estradiol and induces the activity of the transcription factor NF-kappaB. J Neural Transm 2000;107:393-407.
11 Jang JH, Surh YJ: Protective effects of resveratrol on hydrogen peroxide-induced apoptosis in rat pheochromocytoma (PC12) cells. Mutat Res 2001;496:181-190.

12 Koo BS, Lee WC, Chung KH, Ko JH, Kim CH: A water extract of Curcuma longa L. (Zingiberaceae) rescues $\mathrm{PC} 12$ cell death caused by pyrogallol or hypoxia/reoxygenation and attenuates hydrogen peroxide induced injury in $\mathrm{PC} 12$ cells. Life Sci 2004;75:2363-2375.

13 Godkar PB, Gordon RK, Ravindran A, Doctor BP: Celastrus paniculatus seed water soluble extracts protect against glutamate toxicity in neuronal cultures from rat forebrain. J Ethnopharmacol 2004;93:153-432.

14 Hwang IK, Yoo KY, Kim DS, Jeong YK, Kim JD, Shin HK, Lim SS, Yoo ID, Kang TC, Kim DW, Moon WK, Won MH: Neuroprotective effects of grape seed extract on neuronal injury by inhibiting DNA damage in the gerbil hippocampus after transient forebrain ischemia Life Sci 2004; 75:1989-2001.

15 Iinuma M, Tosa H, Tanaka, T, Asai F, Kobayashi Y, Shimano R, Miyauchi K: Antibacterial activity of xanthones from guttiferaeous plants against methicillin-resistant Staphylococcus aureus. J Pharm Pharmacol 1996;48: $861-865$.

16 Nakatani K, Nakahata N, Arakawa T, Yasuda $\mathrm{H}$, Ohizumi Y: Inhibition of cyclooxygenase and prostaglandin $\mathrm{E}_{2}$ synthesis by $\gamma$-mangostin, a xanthone derivative in mangosteen, in C6 rat glioma cells. Biochem Pharmacol 2002; 63:73-79.

17 Nakatani K, Atsumi M, Arakawa T, Oosawa K, Shimura S, Nakahata N, Ohizumi Y: Inhibitions of histamine release and prostaglandin E2 synthesis by mangosteen, a Thai medicinal plant. Biol Pharm Bull 2002;25:1137-1141.
18 Chen SX, Wan M, Loh BN: Active constituents against HIV-1 protease from Garcinia mangostana. Planta Med 1996;62:381-382.

19 Moongkarndi P, Kosem N, Kaslungka S, Luanratana O, Pongpan N, Neungton N: Antiproliferation, antioxidation and induction of apoptosis by Garcinia mangostana (mangosteen) on SKBR3 human breast cancer cell line. J Ethnopharmacol 2004;90:161-166.

20 Mahakunakorn P, Tohda M, Murakami Y, Matsumoto K, Watanabe H, Vajaragupta O: Cytoprotective and cytotoxic effects of curcumin: dual action on $\mathrm{H}_{2} \mathrm{O}_{2}$-induced oxidative cell damage in NG108-15 cells. Biol Pharm Bull 2003;26:725-728.

21 Hara H, Ohta M, Ohta K, Kuno S, Adachi T: Increase of antioxidative potential by tert-butylhydroquinone protects against cell death associated with 6-hydroxydopamine-induced oxidative stress in neuroblastoma SH-SY5Y cells. Mol Brain Res 2003;119:125-131.

22 Mahakunakorn P, Tohda M, Murakami Y, Matsumoto K, Watanabe H: Antioxidant and free radical-scavenging activity of Choto-san and its related constituents. Biol Pharm Bull 2004;27:38-46.

23 Blois MS: Antioxidant determination by the use of a stable free radical. Nature 1958;181: 1199-1200.

24 Vajraguptaa $\mathrm{O}$, Watanabe $\mathrm{H}$, Boonyarata $\mathrm{C}$ : A novel neuroprotective agent: a dual action of radical scavenger and nitric oxide synthase inhibitor. 18th Int Symp on Medicinal Chemistry, Copenhagen and Malmö, 2004, poster 123.

$\checkmark 25$ Ahlemeyer B, Junker V, Hühne R, Krieglstein $\mathrm{J}$ : Neuroprotective effects of NV-31, a bilobalide-derived compound: evidence for an antioxidative mechanism. Brain Res 2001; 890:338-342. 
26 Vajragupta $\mathrm{O}$, Boonchoong $\mathrm{P}$, Watanabe $\mathrm{H}$, Tohda M, Kummasud N, Sumanont Y: Manganese complexes of curcumin and its derivatives: evaluation for the radical scavenging ability and neuroprotective activity. Free Radic Biol Med 35;2003:1632-1644.

- 27 Brown DA, Higashida H: Inositol 1,4,5-trisphosphate and diacylglycerol mimic bradykinin effects on mouse neuroblastoma $\times$ rat glioma hybrid cells. J Physiol 1988;397:185207.

28 Schmitt H, Meves H: Model experiments on squid axons and NG108-15 mouse neuroblastoma $\mathrm{x}$ rat glioma hybrid cells. J Physiol Paris 1995;89:181-193.

29 Halliwell B, Gutteridge JM, Cross CE: Free radicals, antioxidants, and human disease: where are we now? J Lab Clin Med 1992;119: 598-620.

30 Reiter RJ, Acuna-Castroviejo D, Tan DX, Burkhardt S: Free radical-mediated molecular damage: mechanisms for the protective actions of melatonin in the central nervous system. Ann NY Acad Sci 2001;939:200-215.
Kang SS, Lee JY, Choi YK, Kim GS, Han BH Neuroprotective effects of flavones on hydrogen peroxide-induced apoptosis in SH-SY5Y neuroblastoma cells. Bioorg Med Chem Lett 2004; 14:2261-2264.

32 Dok-Go H, Lee KH, Kim HJ, Lee EH, Lee J, Song YS, Lee YH, Jin C, Lee YS, Cho J: Neuroprotective effects of antioxidative flavonoids, quercetin, (+)- dihydroquercetin and quercetin 3-methyl ether, isolated from Opuntia ficus-indica var. saboten. Brain Res 2003; 965:130-136.

33 Hyslop PA, Hinshaw DB, Schraufstatter IU, Sklar LA, Spragg RG, Cochrane CG: Intracellular calcium homeostasis during hydrogen peroxide injury to cultured P388D1 cells. J Cell Physiol 1986;129:356-366.

34 Hyslop PA, Hinshaw DB, Halsey WA Jr, Schraufstatter IU, Sauerheber RD, Spragg RG Jackson JH, Cochrane CG: Mechanisms of oxidant-mediated cell injury: the glycolytic and mitochondrial pathways of ADP phosphorylation are major intracellular targets inactivated by hydrogen peroxide. J Biol Chem 1988;263: 1665-1675.
Barbouti A, Doulias PT, Nousis L, Tenopoulou M, Galaris D: DNA damage and apoptosis in hydrogen peroxide-exposed Jurkat cells: bolus addition versus continuous generation of $\mathrm{H}(2) \mathrm{O}(2)$. Free Radic Biol Med 2002;33:691702 .

36 Chandra J, Samali A, Orrenius S: Triggering and modulation of apoptosis by oxidative stress. Free Radic Biol Med 2000;29:323-333.

37 Hayashi $\mathrm{H}$, Tohda M, Watanabe H, Murakami Y, Matsumoto K: The effects of Choto-san on the mRNA expression of Alzheimer's disease related factors in the permanent ischemic rat brain. Biol Pharm Bull 2005;28:744-746.

38 Dohi K, Aruga T, Satoh K, Shioda S: Chotosan (kampo Medicine) for the treatment of headache. Headache 2004;44:375.

39 Watanabe $\mathrm{H}$, Zhao Q, Matsumoto K, Tohda M, Murakami Y, Zhang SH, Kang TH, Mahakunakorn P, Maruyama Y, Sakakibara I, Aimi N, Takayama H: Pharmacological evidence for antidementia effect of Choto-san (Gouteng-san), a traditional Kampo medicine. Pharmacol Biochem Behav 2003;75:635643 